\title{
Yarasa ve orman ilişkisi üzerine bir değerlendirme
}

\author{
Tarkan YORULMAZ (Orcid: 0000-0002-9033-7162) ${ }^{*}$, Okan ÜRKER (Orcid: 0000-0002-5103-7757)², \\ Rıdvan ÖZMEN (Orcid: 0000-0001-9251-3353) \\ ${ }^{1}$ Cankırı Karatekin Üniversitesi, Fen Fakültesi, ÇANKIRI \\ ${ }^{2}$ Çankırı Karatekin Üniversitesi, Fen Bilimleri Enstitüsü, ÇANKIRI \\ *Sorumlu yazar/Corresponding author: tyorulmaz@karatekin.edu.tr, Geliş tarihi/Received: 10.01.2018, Kabul tarihi/Accepted: 21.01.2018
}

\section{$\ddot{O} z$}

Dünyada 5490 memeli türü yayılış göstermektedir. 1300 türle yarasalar toplam memelilerin yaklaşık dörtte birini oluşturmaktadır. Yarasalar beslenmek, tünemek ve üremek için çok farklı habitatları ve ekosistemleri kullanabilirler. $\mathrm{Bu}$ alanların en önemlilerinden biri ormanlardır. Ormanlar, yarasaların kimi zaman tüneme ve barınma yeri iken, kimi zaman da beslenme alanlarıdır. Bu çalışmada, ormanların yarasalar açısından önemi ve yarasaların ormanlarda yaşadıkları genel problemlere yönelik çözüm önerilerine vurgu yapılmak istenmiştir. Türkiye'de yaşayan 39 yarasa türünün 30'unun ormanla doğrudan veya dolaylı yönden ilişkili olduğu ifade edilmiştir. Yarasaların tüneme ve beslenmeleriyle ilgili çalışmalar derlendiğinde, Türkiye'de ormanla ilişkisi tespit edilmiş 30 yarasa türünden 28'inin ormanları beslenme amaçlı kullandığı kaydedilmiştir. Ormanlarla ilişkili olduğu ifade edilen bu 30 yarasa türünden 15'inin ise ormanları tüneme amaçlı kullandığı rapor edilmiștir. Yarasaların ormanlarda yaşlı ağaçları, gevşek kabuk arkalarını, bazı kuş yuvalarını, devrilmiş ağaç kütüklerini, çeşitli doğal süreçlerle oluşmuş ağaç yarıklarını, kovuklarını ve boşluklarını tercih ettiği bilinmektedir. Yarasaların yaşaması muhtemel olan ormanlık alanlarda 1ş1k tuzakları, dedektörler ve ağlar kullanılarak teşhisleri yapılabilmektedir. Ayrıca yarasalara takılan izleme cihazları ile orman içerisinde hangi alanları tüneme ve beslenme amacıyla tercih ettikleri, mevsimsel olarak orman içerisindeki aktivitelerinin nasıl olduğu da izlenebilmektedir. Orman alanlarında bilinçsiz ve kontrolsüz ağaç kesimleri, çeşitli nedenlere bağlı gözlenen habitat parçalanmaları, orman yangınları, böceklere yönelik kimyasal mücadele, madencilik faaliyetleri ve rüzgâr türbinlerinin kurulması gibi insan faaliyetleri, ormanı kullanan yarasaları tehdit etmektedir. Bu tarz olumsuz insan faaliyetlerinin önlenebilmesi için orman amenajman planlarına biyolojik çeşitlilik verilerinin entegrasyonu, böceklerle biyolojik mücadele, bilimsel odaklı çevresel etki değerlendirme çalışmaları ve halkın bilinçlendirilmesi gibi çalışmalara ihtiyaç duyulmaktadır.

Anahtar kelimeler: Orman, yarasa, yarasa ekolojisi, doğa koruma

\section{An evaluation on the relation of bat and forest}

\begin{abstract}
There are 5490 mammal species in the world. Approximately one quarter of them are the bats. The bats use very different habitats to feed, roost and breed. One of the most important habitats, the forests are also used as roosting, resting, breeding and feeding places by bats. In this study, it is aimed to emphasize the importance of the forests for bats and the conservation suggestions regarding the challenges that forests pose for bats. It was stated out that 30 out of 39 bat species in Turkey are directly or indirectly related to the forests. 28 of these 30 species use the forest for feeding and 15 species of them use it as roosting places. It is known that the bats prefer aged trees, loose bark backs, some bird nests, overturned tree logs, tree crevices, cavities and voids formed by various natural processes in the forests. The light traps, detectors, sweep nets and the tracking devices are used to identify the bats and understand their feeding, breeding, hibernation and roosting areas in the forests seasonally. The general threats against the bats in the forests may be summarized as unconscious and uncontrolled tree cuttings, habitat fragmentations, forest fires, chemical pest control, mining activities and establishment of wind turbines. Studies on integration of biological diversity data into the forestry management plans, biological pest control, science-based environmental impact assessment, and public awareness activities are required in order to prevent these problems.
\end{abstract}

Keywords: Forest, bat, bat ecology, nature conservation

To cite this article (Atıf): YORULMAZ, T , ÜRKER, O, ÖZMEN, R . (2018) . Yarasa ve orman ilişkisi üzerine bir değerlendirme. Ormancılık Araştırma Dergisi, 5(1), 31-43.

DOI: DOI:http://dx.doi.org/10.17568/ogmoad.377123

\section{Giriş}

Dünyada 5490 memeli türü yayılış göstermektedir. Memelilerin içinde 32 familya ve yaklaşık
2300 türü ile kemiriciler en kalabalık takımı oluşturmaktadır (Wilson ve Reeder, 2005). Memeli sınıfının tür bakımından en zengin ikinci takımı ise 18 familya, 197 cins ve yaklaşık 1300 türü ile 
yarasalard1r (Merrit, 2010; Richardson, 2011; Bogdanowicz ve ark., 2014). Hayvanlar (Animalia) âlemine ait memeli (Mammalia) sınıfı içindeki gerçek uçuş özelliği gösteren tek takım yarasalardır (Albayrak, 1999). Türkiye'de biri Megachiroptera, 38'i Microchiroptera altordosuna ait 39 yarasa türü yayılış göstermektedir (Yorulmaz ve Arslan, 2016a; Yorulmaz ve ark., 2016).

Yarasalar beslenmek, tünemek ve üremek için farklı habitat ve yapıları kullanabilirler. Bu habitatlardan en önemlilerinden biri ormanlardır. Ormanlar yarasaların kimi zaman tüneme ve barınma yeri iken, kimi zaman da beslenme alanlarıdır. Orman içinde bulunan yaşlı ve kovuğa sahip ağaçlar pek çok yarasanın tünemesi için ideal ortamlar sağlamaktadır. Bu bağlamda ormanı tünemek, üremek ve/veya beslenmek amacıyla kullandığı bilinen yarasaların orman ve ağaçlarla ilişkisinin bilinmesi ve Türkiye'de ormancılık faaliyetlerinin bu bilgiye göre yönetilmesi günümüzde ekolojik ormancılığın önemli aşamalarından biri olacaktır. Bu çalışma ormancılık faaliyetlerinde yarasaların önemini, yönetiminin ve izlenmesinin nasıl olması gerektiğini vurgulamak amacıyla gerçekleştirilmiştir.

\section{Yarasalar için ormanlar}

Yarasalarla ormanlar arasında önemli derecede yüksek ve süreklilik arz eden bir ilişki olduğu belirtilmiştir (Waldien ve Hayes, 2001). Türkiye'de bulunan 39 yarasa türünden 30'u ormanı tünemek ya da avlanmak için kullanmaktadır (Yorulmaz ve ark., 2016). Türkiye'deki yarasalar beslenmek amac1 ile özellikle çayırlar, sucul habitatlar ve ormanları tercih etmektedir. Orman alanları kendilerine özgü ekosistemleri ile yarasalar için barınak ve beslenme alanı olmaktadır. Orman ekosistemlerinin gizemli türleri olan yarasalar orman içinde var olan böcekleri tüketmektedir. Böylece orman içindeki zararlı böcek popülasyonlarının dengelenmesi sağlanmaktadır. Yarasalar genellikle mağara türleri olarak bilinmektedir. Ancak çoğu yarasa türü bütün yaşamı boyunca ormana bağımlıdır. Yarasaların korunması ve yönetimi yaşam alanları olan ormanların sağlıklı olmasına bağlıdır.

Yarasalar ormanları ağaçlarda tünemek, beslenmek ve avcılarından kaçınmak için kullanmaktadır (Taylor, 2006). Tünekler yarasalar için kritik önem taşırlar, çünkü yarasalar bu tünekleri kötü hava koşullarından ve potansiyel yırtıcılardan korunma, çiftleşme yeri, büyüme, kış uykusunu geçirme, besinleri sindirme ve diğer bireylerle sosyal olarak etkileşim kurma faaliyetlerinde yoğun olarak kullanmaktadır (Anthony ve Kunz, 1977).

\subsection{Türkiye ormanları}

Türkiye, kuzeyde Sibirya fitocoğrafik bölgesi, güney ve batıda Akdeniz fitocoğrafik bölgesi ve orta ve doğu Anadolu'da ise İran-Turan fitocoğrafik bölgesi bulunduğundan zengin bir bitki çeşitliliğine sahiptir (Eken ve ark., 2006). Bu durum orman varlığı ve orman ekosistem çeşitliliğine de yansımaktadır. $\mathrm{Bu}$ nedenle birbirinden farklı özellikleri bulunan Türkiye'deki orman ekosistemlerinin sürdürülebilir yönetiminin sağlanması da önemli bir konudur. Orman Genel Müdürlüğünün (OGM) 2015 yılında hazırladığı Türkiye'nin Orman Varlığ 1 envanter verilerine göre ormanlık alanlar, ülke alanının yaklaşık \%28,6'sını kaplamaktadır. Aynı raporda ormanların fonksiyonlarını ve alanlarını belirlemenin sürdürülebilir orman yönetimi açısından önem arz ettiği de ifade edilmiştir (OGM, 2015). Bu çerçevede, ekosistem yaklaşımını, katılımcılığı ve fonksiyonel planlamayı esas alan "Ekosistem Tabanl1 Fonksiyonel Orman Amenajman Yönetmeliği" 05.02.2008 tarihli ve 26778 sayılı Resmî Gazetede yayımlanarak yürürlüğe konmuştur. $\mathrm{Bu}$ yönetmeliğe göre; devlet ormanlarının işletme gayeleri, ulusal ormancılık programı çerçevesinde, ormanların ekonomik, ekolojik ve sosyokültürel fonksiyonları dikkate alınarak katılımcılık ve ekosistem tabanlı fonksiyonel planlama yaklaşımı hedef alınarak Orman Genel Müdürlüğü tarafından belirlenmekte, orman amenajman planları hazırlanmakta ve uygulanmaktadir (OGM, 2015).

\subsection{Yarasaların ormanda beslenme stratejileri}

Farklı vücut formundaki yarasalar, farklı hareket ve uçuş kabiliyetine sahiptir. Bu nedenle kullandıkları habitatlar değişiklik göstermektedir. Örneğin, uzun kanatlı yarasalar hizlı olup daha uzaklara uçabilme kabiliyetine sahip olduklarından orman üstünden beslenmeyi tercih etmektedir. Buna karşın, geniş kanatlı yarasalar ise yakın mesafeli uçarlar ve yüksek manevra kabiliyetine sahip olduklarından orman içerisinde beslenebilirler. Hız ve manevra kabiliyeti yüksek olan uzun ve geniş kanatlı yarasalar ise orman içi açıklıklar, yollar ve orman sınırlarında beslenebilirler (Neuweiler, 1990).

\section{Türkiye'de bulunan yarasaların tüneme ve beslenme yerleri}

Türkiye'de 5 familyaya bağlı 39 tür yarasa bulunmaktadır. Bu yarasa türlerinin beslenme ve tüneme yerleri bugüne kadar Türkiye yarasaları ile ilgili yapılmış çalışmalar ve aynı türlerin habitat tercihleri ile ilgili yapılmış çalışmalar dikkate alınarak değerlendirilmiştir (Yorulmaz ve Arslan, 2016b). $\mathrm{Bu}$ değerlendirmeler sonucunda Türkiye'deki 39 
yarasanın \%77'si tüneme ve beslenme için orman ekosistemini (Şekil 1, Şekil 2, Şekil 3) tercih etmektedir (Dietz ve ark., 2009; Yorulmaz ve ark., 2016b).

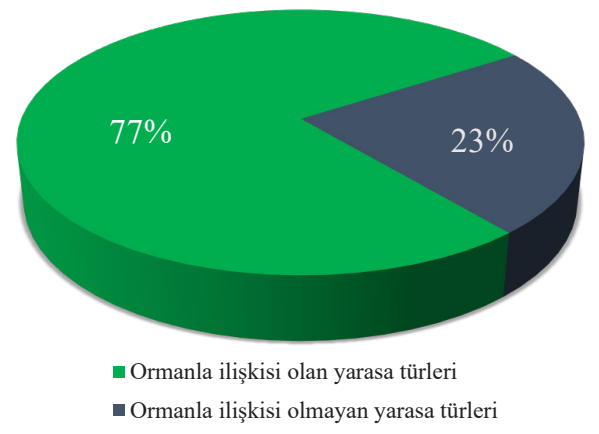

Şekil 1. Türkiye'de yaşayan 39 yarasa türünün beslenme ve/veya tüneme amaciyla ormanları kullanma oran 1

Figure 1. The distribution of 39 bat species in forests for feeding and/or roosting in Turkey

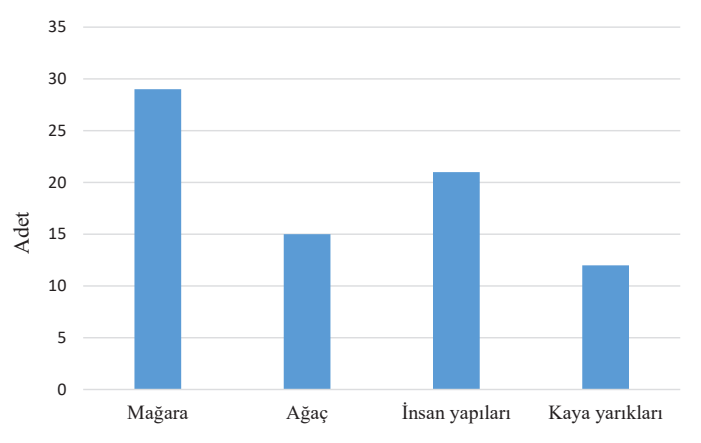

Şekil 2. Türkiye'de yaşayan yarasa türlerinin tüneme alanlarına göre dağılımı

Figure 2. The distribution of the preference of the different roosting places of the bats in Turkey

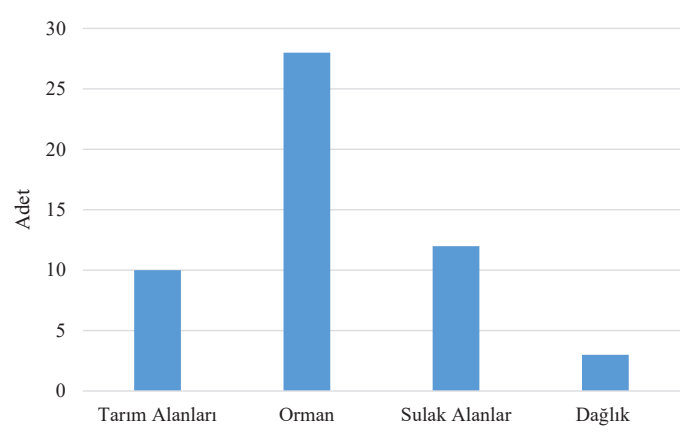

Şekil 3. Türkiye'deki yaşayan yarasa türlerinin beslenme alanı tercihlerine göre sayısal dağılımı

Figure 3. The distribution of the preference of the different feeding places of the bats in Turkey

\section{Yarasalar için potansiyel tünek özellikleri}

Bazı araştırmacılar tüneme aktivitelerinin, yarasa topluluklarının çeşitliliğini etkilediğini (Humphrey, 1975), oyukların tahrip edilmesi ile birlikte yarasa popülasyonlarında azalma olduğunu belirtmiştir (Evelyn ve ark., 2004; Lunney ve ark., 1988). Tüneklerin gündüz ve gece boyunca veya kış uykusu sırasında kullanılmasının yanı sıra, yırtıcılardan ve çevre koşullarından korunmanın bir yolu olarak da tercih edildiği ifade edilmiştir (O'Shea ve Bogan, 2003). Buna ek olarak, beslenme alanı ile tüneme yeri arasındaki mesafenin kısaltılması amacıyla orman içinde beslenen pek çok yarasa türü de ağaçları tüneme amaçlı kullanmaktadır (Speakman ve Thomas, 2003). Yarasalar, ağaçların üzerindeki ağaç boşluklarını, ağaçkakan gibi kuşların açtıkları delikleri, doğal çürüme ile oluşan çatlakları, kısmen ayrılmış kabukların gevşek kabuk altlarını, yıldırım çarpması gibi doğal süreçlerle oluşabilen yarıkları tüneme amacıyla kullanabilmektedir (Jackson, 2015) (Şekil 4). Ayrıca yarasalar, yönlerini bulmak, avcılardan ve tehlikeli hava koşullarından korunmak için de ağaçları kullanabilirler. Tüneme ağaçlarının mevcut ağaçlardan çok daha uzun boylu ağaçlar olduğu tespit edilmiştir (Brigham ve ark., 2002; Evelyn ve ark., 2004; Vonhof ve ark., 2004).

\section{Ormanlarda yarasalar nasıl tespit edilmektedir?}

Ormanları çeşitli amaçlarla kullanan yarasa türlerinin uzun vadeli korunmasını sağlamak amacıyla izleme çalışmalarının yapılması önemlidir. Genel olarak ormanlarda yaşayan yarasaları izlerken çalışılacak alanın coğrafi konumu, iklimsel özellikleri (yıl içinde ortalama sıcaklık-nem-rüzgâr değişimleri, en sıcak ve soğuk aylar, yıllık yağış vb.), su kaynaklarına olan mesafesi, yüz ölçümü, bölgenin bitki örtüsü, meşcere yapısı, iğne yapraklı ya da karışık olması vb.) belirlenerek çalışılacak alan paftalara ayrılmaktadır. Her bir paftada örnekleme işlemleri gerçekleştirilir. Çalışılacak ekipmanlar örnekleme metoduna uygun bir şekilde tespit edilir. Bu ekipmanlar, ultrasonik dedektörler, halkalar, radyo vericileri, çeşitli gözenek aralığına sahip ağlar, ultraviyole 1şıklar, yarasa kutuları, eldiven ve fener olarak sıralanabilir. Örnekleme metodu, kullanılacak ekipmanlar ve iş akışının belirlenmesinin ardından genellikle yarasaların aktif olduğu dönemlerde (çoğunlukla Mayıs-Ekim ayları arasında) örnekleme çalışmalarına başlanılmaktadır (Kunz ve ark., 1996; Taylor, 2006; Tillion ve ark.,2016). 


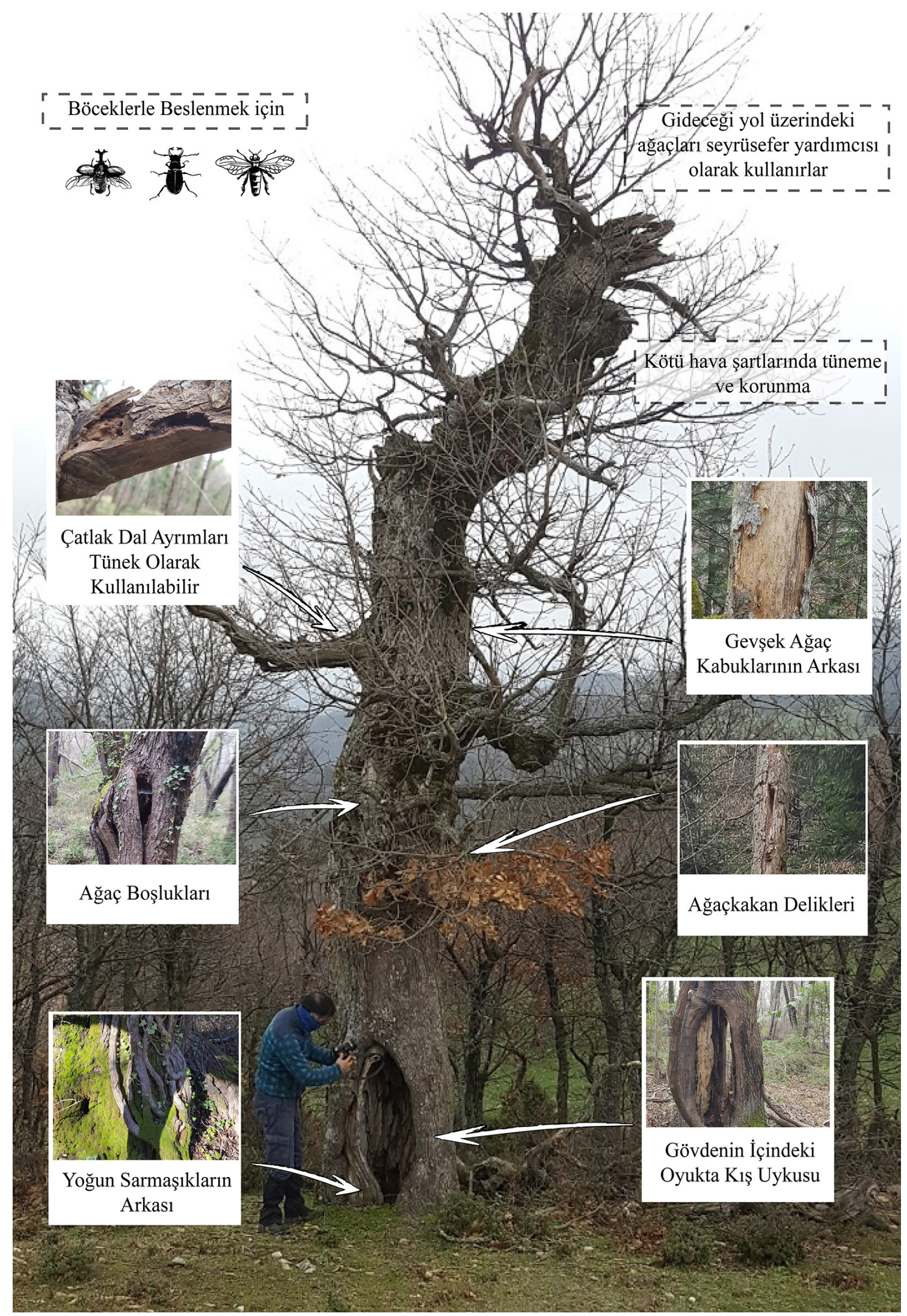

Șekil 4. Yarasaların ağaçları kullanımına ilișkin genel bir özet Figure 4. A summary of bats' tree use 


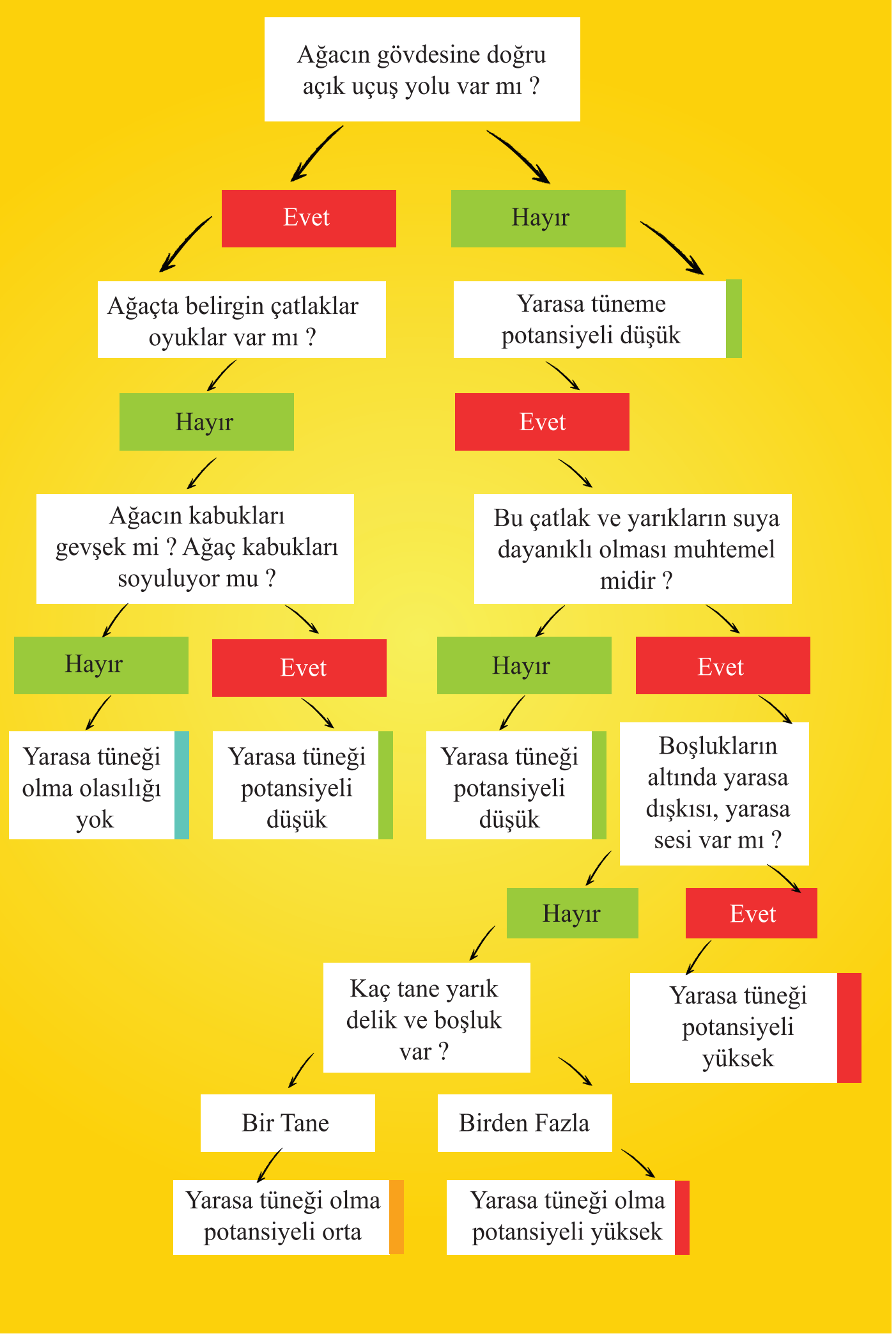

Şekil 5. Ormancılık uygulamaları sırasında ağaçlarda tüneyen yarasaların tespiti için önerilen bir yol Figure 5. Suggested method to determine the bats roosting on the trees during forestry applications 
Orman içerisindeki araştırmalarda son yıllarda özellikle dolaylı bir tespit metodu olan ultrasonik dedektörler kullanılarak ekolokasyon çağrılarının izlenmesi ve bunların istatistiksel olarak yorumlanması şeklinde yarasaların ormanlardaki yaşam özellikleri ortaya konulmaktadır (Taylor 2006). Orman içerisindeki doğrudan tespit ve inceleme yöntemleri ise yarasa kutularının yerleştirilmesi, atrap kullanımı, çeşitli boyutlardaki özel yarasa ağlarıyla yapılan yakalama işlemleri ve bunların sonucunda yarasalara takılan izleme halkaları ve uydu vericileri olarak özetlenebilir (Kuntz ve ark., 1996; Kunz 1998; Hundt, 2012).

Öte yandan çalışılan orman alanı ile bağlantılı olduğu düşünülen yakın çevredeki mağara, in, boş bina, çatı arası ve benzeri yerler de gündüz veya gece özel eldivenler, el veya baş feneri yardımıyla doğrudan araştırılarak orman ile ilişkileri incelenebilmektedir (Kuntz ve ark., 1996; Kunz 1998; Hundt, 2012). Bununla beraber orman içerisinde yarasaların doğrudan tespiti için ultraviyole 1şınlar kullanılarak böceklerin ışı̆̆a gelmesi sağlanabilmekte ve bu böceklerden beslenen yarasaların daha rahat örneklenebilmesi açısından bu noktalara gelmeleri özendirilmektedir (Kuntz ve ark., 1996; Kunz 1998; Hundt, 2012) Yarasa kutuları kullanılarak çalışılan bölgedeki yarasalar mevsimsel olarak düzenli biçimde izlenebilmektedir (Kuntz ve ark., 1996; Kunz 1998; Hundt, 2012). Ayrıca yarasa dışkılarından DNA analiziyle diyet tercihleri de tespit edilebilmektedir (Zelae ve ark., 2011).

\section{Ormanda yaşayan yarasaları etkileyen unsurlar}

Yarasa ve orman ilişkileri bazında yapılan çalışmalarda, gerek ormancılık, gerekse diğer insan aktivitelerinin yarasaları olumsuz etkilediği vurgulanmaktadir (Lacki ve ark., 2007; Huston ve ark, 2001; Yorulmaz ve ark., 2016; Yorulmaz ve Arslan 2016a, 2016b). Bu faaliyetler yoğun ve plansız ağaç kesimleri, madencilik faaliyetleri, orman yangınları, böceklerle mücadele ve rüzgâr türbinleri ana başlikları altında toplanabilir (Tillion ve ark.,2016, ).

Ă̆aç kesimi: Özellikle yarasaların faal olduğu Mayıs-Eylül ayları arasında zorunlu olmadıkça ağaç kesimlerinden kaçınılması gereklidir. Yaşlı ağaçların üzerinde çatlak, yarık ve kabuk boşluğu olma ihtimali yüksek olduğundan, bu ağaçlar yarasalar açısından potansiyel tünek özelliğine sahiptir. Bu nedenle ormanlardaki yaşlı ağaçların azami ölçüde sahada bırakılmasına gayret gösterilmelidir. Yarasalar ağaçları yön ve yol bulmak için kullandıklarından özellikle üreme dönemlerinde tıraşlama kesim metodundan ve orman içinde ağaç çeşitliliğinin değiştirilmesi gibi aktivitelerden uzak durulmalidir.
Uygulamacılar ormanlarda bir ağacın yarasalar tarafından tünek olarak kullanıp kullanmadığını basit aşamalarla kontrol veya tespit edebilirler (Anonim 1, 2018) (Şekil 5). Bu aşamaları gösteren tabloya göre, tünek olma potansiyeli düşükse budama ya da kesim yapılabilir. Ancak ilgili çalışmalar yine de Mart-Temmuz ayları arasında yapılmamalıdır. Ayrıca kabuklarda açıklık varsa dikkat edilmelidir. Eğer tünek olma potansiyeli orta derecede ise yarasalar bazı durumlarda bu ağaçları kullanabilir. Bu tür ağaçlar daha detaylı incelenmelidir. Ağaca müdahale, Eylül ayı ortası ile Kasım ayı ortası arasında yapılmalıdır. Eğer tünek olma potansiyeli yüksek ise, bununla birlikte ağacın kesilmesi veya budanması gerekiyorsa, yarasa yuvası veya tüneği olmadığını kesin olarak ispatlamak gerekir. $\mathrm{Bu}$ ağacın kesilmesi uzman eşliğinde Eylül ayının sonu ile Kasım ayı ortası arasındaki dönemde gerçekleştirilmelidir.

Orman yangınları: Orman yangınları yalnızca ormanlar için değil, hemen hemen yangının gerçekleştiği yakın çevresindeki tüm diğer ekosistemler için de çeşitli tehlikeler barındırmaktadır. Bu nedenle orman yangınları aynı zamanda yarasaları doğrudan tehdit eden bir unsur olmakla beraber dolaylı yoldan yaşam alanlarını da tehdit etmektedir. Orman yangınları ile mücadele edebilmek için öncelikle yangın riskinin ve yangınların fazla olduğu yerler yeniden tespit edilmeli ve bu alanlarda sıcaklık, yağış, bağıl nem ve rüzgâr gibi iklim elemanları sürekli izlenerek yangın sezonlarında çok daha fazla dikkatli olunmalıdır. Yangına duyarlı olan bölgelerdeki ormanlık sahalarda, özellikle yangın mevsimlerinde gerçekleştirilecek turistik aktivitelere yeni düzenlemeler ve kisitlamalar getirilmelidir. Çıkan yangınların büyümeden söndürülmesi için orman alanlarının gerekli yerlerine acil müdahale ekipleri yerleştirilmelidir. Uyarı levhalarının sayısı artırılarak farkındalık ve bilinçlendirme çalışmaları sıklaştırılmalıdır (Perry 2011).

Böceklerle mücadele: Zararlı böcek türlerinin popülasyonlarının belirli düzeyin üzerine çıkması ekonomik açıdan istenmeyen bir durumdur. Özellikle tarım ve ormancılıkta en zararlı hayvanlar böceklerdir. Aşırı üremeleri halinde cüsseleri ile kıyaslanamayacak büyüklükte zararlara sebep olmaktadır. Böceklerin boyutlarının küçük olması, yüksek irtifalardan uçuş yapamamaları, yüksek üreme enerjilerine karşı kısa rejenerasyon süreleri, tam başkalaşımlı hayat dönemine sahip olmaları ve yaşam ortamlarına (orman, toprak vb.) uyum kabiliyetlerinin çok yüksek olması bu hayvanların yaşama şanslarını büyük ölçüde artırmaktadır. 
Ülkemizde zararlı böcekler ile mücadelede bir kısmı çok yoğun, bir kısmı da çok az veya henüz deneme halinde kullanılan 5 yaygın yöntem bulunmaktadır. Bunlar, mekanik mücadele, biyolojik mücadele, kimyasal mücadele, biyoteknik mücadele, biyolojik insektisterle mücadele yöntemleri olarak stralanabilir (Ananonim 2; OGM 2016). Bu yöntemleri kısaca değerlendirdiğimizde, kimyasal mücadele yönteminde aşırı dozda insektisit kullanımı söz konusu olduğu için böcekçil yarasaların besinlerinin de yok edilmesine bağlı olarak yarasa popülasyonlarının dolaylı yolda etkilendikleri bilinmektedir (Hutson 2001). Yarasaların tuzaklara yönelen böceklerin peşinden giderken ilgili tuzaklara yakalanarak ölme riski ile karşı karşıya olmaları nedeniyle ülkemizde sıklıkla kullanılan ve yüksek maliyetli olan feromon tuzakları da ciddi tehlikeler barındırmaktadır (Yorulmaz ve ark., 2016) (Şekil 6). Öte yandan, Türkiye'de zararlı böceklerle mücadele için çeşitli biyolojik yöntemler

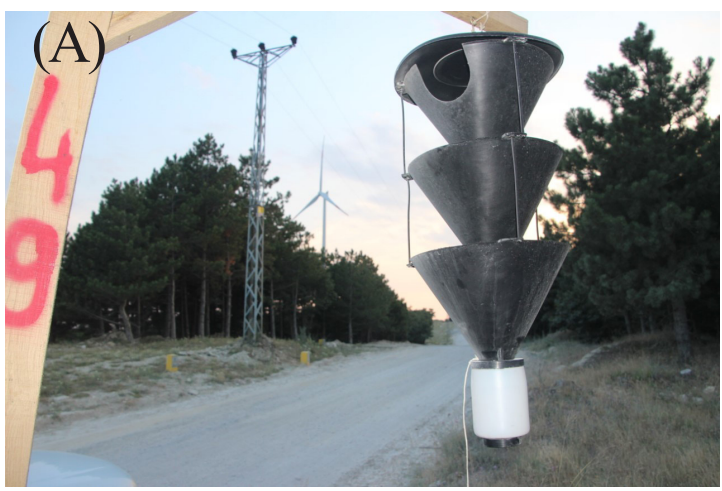

de kullanılmaktadır (Anonim, 2; OGM, 2016).

Şu ana kadar böcek yiyen kuşlar, balık, kurbağa, semenderler ve yırtıcı avcı böcekler kullanılmış; fakat böcek popülasyonlarını çok önemli derecede dengeleme becerisine sahip olan yarasalar ile ilgili henüz bir çalışma yapılmamıştır. Yarasalar özellikle geceleri böceklerle mücadelede çok önemli bir biyolojik unsurdur. Bu noktada yarasa kutularının hem tarımsal arazilerde hem de ormanlık alanlarda kullanılabilir nitelikte olup zararlı böceklerle biyolojik mücadelede büyük başarı elde etme potansiyeline sahip olduğu, ancak bu potansiyelin henüz ülkemizde değerlendirilmediği de ifade edilmelidir (Şekil 7).

Madencilik faaliyetleri: Orman alanı içinde taş ocakları, mermer ocakları, değerli madenler gibi farklı türlerden madenlerin aranması ve işletilmesi doğrudan habitat kayıplarının yanı sıra, deprem etkisi yaratan patlatmalarla yer altı sularının

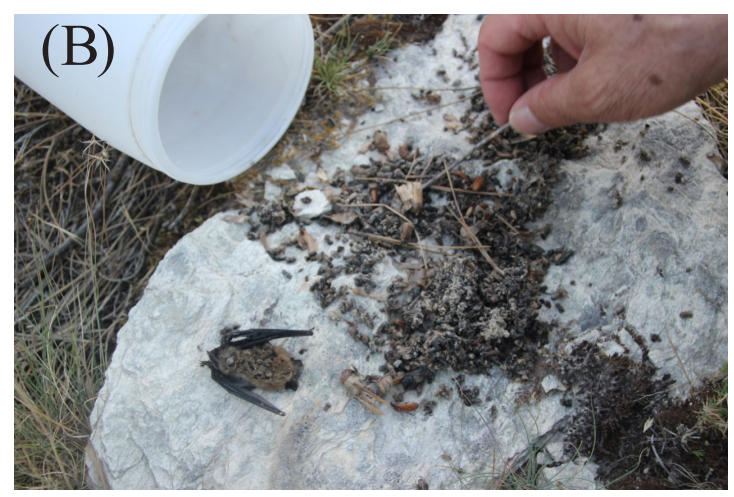

Şekil 6. Zararlı böceklerle mücadele için ormanda kullanılan bir feromon tuzağı (A). Böceği izlerken bu feromon tuzağına düşmüş ölü bir yarasa (B)

Figure 6. A pheromone trap used in pest control (A). A bat that fell on this trap and died while following an insect (B).

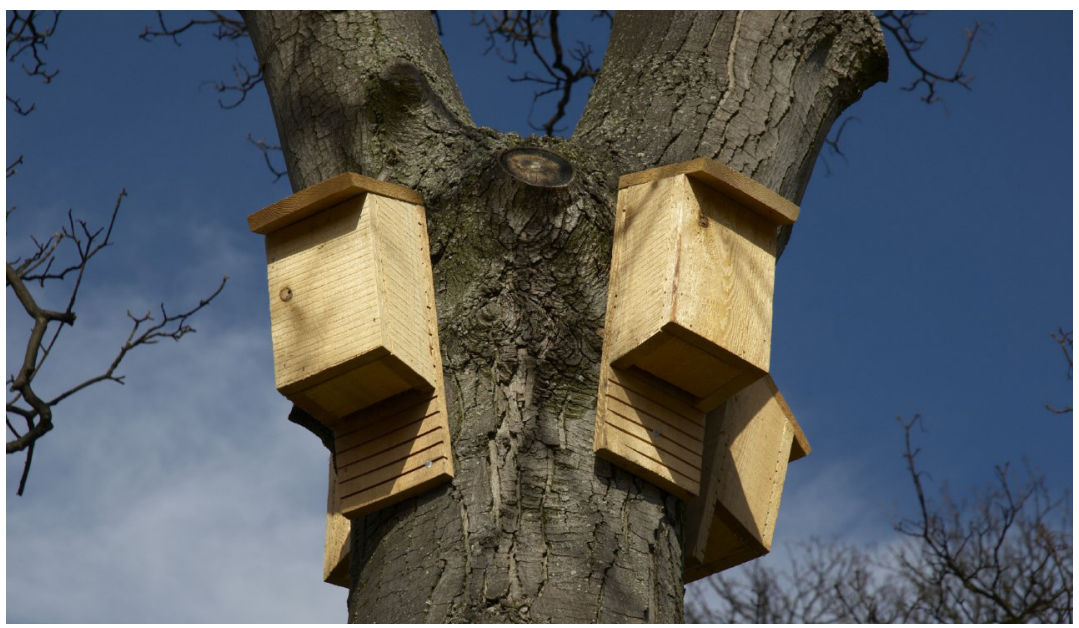

Şekil 7. Yarasa kutularının ağaç üzerindeki kullanımı

Figure 7. The usage of bat boxes on the trees 
tahrip olması, çıkan yoğun toz sonucu ağaçlarda döllenmenin engellenmesi ve sularda oluşan kirliliğe bağlı olarak balık ölümlerinin artması gibi çok ciddi çevresel tahribatlar da yaratmaktadır (Lacki ve ark., 2007; Huston ve ark, 2001). Söz konusu bu tahribatlardan ormanları kullanan yarasalar da strese girme, yaşam alanını kaybetme ve/veya değiştirme, üreme kapasitesinde düşüş ve yavru ölümlerinde artış gibi birçok ciddi tehditle karşı karşıya kalmaktadır (Lacki ve ark., 2007; Huston ve ark, 2001). Taş ocaklarının orman ve su üretim alanlarıyla yerleşim yerlerinin uzağında ve ağaçlandırılamayacak kayalık arazilerde açılması, madenin işi bittikten sonra ağaçlandırma ve düzenleme çalışmaları yapılması ormanı kullanan yarasaların bu tarz faaliyetlerden minimum düzeyde etkilenmesi açısından ciddi fayda sağlayacaktır (Lacki ve ark., 2007; Huston ve ark, 2001).

Rüzgâr türbinleri: Orman alanlarında kurulan rüzgâr türbinlerine bağlı olarak ta yarasalar ve kuşların rüzgâr türbinleri ile etkileşime girerek çarpışma, basınç gibi direkt etkiler ile habitat kayıpları, trafik, gürültü, toz benzeri dolaylı etkilere de maruz kalmalarıyla türlerin popülasyon yoğunluklarında ciddi baskılar gözlenebilmektedir (Hutson ve ark., 2001; Yorulmaz, 2013). Bu tarz etkileri asgari düzeylerde tutabilmek amacıyla ilgili tesisi inşa ederken örneğin yakınlarında kuşların veya yarasaların yuvalarının ve tüneme alanlarının olup olmadığına ya da göçmen kuşların konaklama noktalarının bu çevrelerde bulunup bulunmadığına, mağara ve su kaynağı gibi yarasaları cezbedecek alanların olup olmadığına dikkat edilmelidir. $\mathrm{Bu}$ noktalara önem verilirse, kuşkusuz ortaya çıkacak çok sayıda zararın önüne geçilmiş olacaktır (Hutson ve ark., 2001; Yorulmaz, 2013).

\section{Sonuç ve Tartışma}

$\mathrm{Bu}$ çalışma kapsamında derlenen çalışmalar dikkate alındığında ormana bağımlı yarasaların varlığına bağlı olarak orman yapısının yönetimi hakkında bazı önerilerde bulunulmuştur. Türkiye, yüzölçümünün yaklaşık \%27'si orman alanları ile kaplı bir ülke olmasının yanı sıra, 38'i böcekle ve 1 tanesi meyve ile beslenen toplam 39 yarasaya da ev sahipliği yapmaktadır. Bununla birlikte Türkiye yarasalarının yaklaşık \%77'sinin de beslenmek ve/ veya tünemek için ormanda oldukları bilinmektedir (Yorulmaz ve ark., 2016; Yorulmaz ve Arslan 2016a, 2016b). Ancak bu bilgilere rağmen, bugüne kadar Türkiye'de orman ve yarasaları konu eden çalışmalara rastlanılmamaktadır.

Son yıllarda Orman Genel Müdürlüğü tarafından amenajman planlarının orman içi biyolojik çeşitliliğin de dikkate alınarak revize edilmeye başlanmış olması önemli bir adımdır. Ormancılık faaliyetleri, orman yangınları, orman için doğal kaynakların kullanımına yönelik faaliyetler, orman içi zararlı böceklerle mücadelede kimyasalların kullanımı, orman içi madencilik faaliyetleri ve son dönemlerde giderek artan Rüzgâr Enerji Santrallerinin (RES) orman alanlarına da kurulması gibi durumlarda ormana bağımlı yarasa türlerinin izlenmesi ve korunması çalışmaları daha çok önem kazanmaktadır. İlgili faaliyetlerin ormanları kullanan yarasalara yönelik olası ve doğrudan etkilerini azaltmak amacryla bu tarz faaliyetlere başlanmadan önce mutlaka ormana bağımlı yarasa türlerinin belirlenmesi, tespit edilenlerin içerisinde koruma önceliği olan türlerin ve ormanla ilişkilerinin ortaya konulması gerekmektedir.

Orman içerisinde bahsi geçen bu faaliyetlerin gerçekleştirilmesi durumunda yarasaların korunmasına yönelik tedbirler üç farklı aşamada ele alınmalıdir (Hutson ve ark., 2001):

-Tüneme alanları: Yarasalar genel olarak karan$11 \mathrm{k}$, nispeten nemli ve $1 \mathrm{l} \mathrm{k}\left(15-30{ }^{\circ} \mathrm{C}\right)$ alanları tünemek için kullanırlar. Bu alanlar mağaralar, terkedilmiş yapılar, ağaç kovukları ve kaya yarıkları gibi alanlardır. Orman içlerinde bu yapılar tespit edilerek mümkün olduğunca korunmalıdır.

-Beslenme alanları: Yarasalar genellikle yüksek bitki örtüsüne sahip alanları ve su kıyılarını beslenmek için kullanırlar. Orman ekosistemlerinde ise orman içi açıklıklar, orman içi dereler, geniş yapraklı ormanlar ve karışık orman özelliği gösteren habitatlar öncelikli beslenme alanlarıdır. Bu alanlarda ormancılık faaliyetleri, alanın mevcut örüntüsünü değiştirmeyecek düzeyde yapılmalıdır.

-Biyolojik döngüleri: Yarasalar Ekim-Nisan ayları arasında tüneme noktalarında kış uykusuna yatarlar. Bu alanlar ağaç kovukları, ağaçkakan yuvaları, kabuklu ağaçların kabuk altları olabilmektedir. $\mathrm{Bu}$ dönemde yapılacak ağaç kesimlerinde yarasaların yaşayabileceği ağaçlarda hayvan varlığına dikkat edilmelidir. Yarasalar, Haziran-Temmuz ayları arasında ise yavrulama ve yavru bakımı aşamasındadır. $\mathrm{Bu}$ dönemlerde yapılacak ormancılık faaliyetlerinde de özellikle kesimi yapılacak ağaçların kovuk ve kabuk durumu kontrol edilerek hayvan varlığı dikkate alınmalıdır. Ağustos-Eylül aylarında ise yarasalar çiftleşme aşamasında olup, bu dönemde yoğun göç hareketleri ve beslenme faaliyetleri sergilemektedirler. Bu dönemlerde yarasaların ses kayıtlarının alındığı yani beslenmeleri için önemli alanlarda keskin habitat değişimine yol açacak faaliyetler yapılmamalıdır. Bu bilgiler doğrultusunda, yarasa türlerini korunma önceliği sırasına göre 3 gruba ayırarak bir öneri sunulabilir 
(Hutson ve ark., 2001; Taylor 2006; Lacki ve ark., 2007; Yorulmaz ve ark., 2016; Yorulmaz ve Arslan 2016a, 2016b):

-Koruma önceliği olan türler: Uluslararası Doğa Koruma Birliği (IUCN Red List, 2017) kriterle- rine göre bir statüde sınıflandırılan yarasa türleri ile Türkiye'de yaşayan yarasa türlerinin koruma statüleri ve durumları aynı değildir. Bu sebeple bu çalışmada koruma önceliklerine göre verilen türler IUCN'nin koruma statülerine ek olarak Türkiye'deki popülasyon durumu (Yorulmaz ve ark.,

Tablo 1. Koruma önceliği olan yarasa türleri

Table 1. Bat species with protection priority

\begin{tabular}{|c|c|c|c|c|}
\hline Türler & Türkçe ismi & Beslenme yerleri & Tüneme yerleri & $\begin{array}{c}\text { IUCN } \\
\text { tehlike } \\
\text { kategorisi }\end{array}$ \\
\hline Rousettus aegyptiacus & Misır meyve yarasası & Meyve bahçeleri & $\begin{array}{c}\text { Mağara, terk edilmiş } \\
\text { binalar, }\end{array}$ & $\mathrm{LC}$ \\
\hline Rhinolophus mehelyi & Nalburunlu yarasa & Bozkır, çayır otlak & Mağaralar & VU \\
\hline Rhinolophus euryale & $\begin{array}{c}\text { Akdeniz nalburunlu } \\
\text { yarasas } 1\end{array}$ & $\begin{array}{c}\text { Ormanlık, çalılık } \\
\text { alanlar }\end{array}$ & $\begin{array}{l}\text { Doğal ve yapay } \\
\text { mağaralar }\end{array}$ & NT \\
\hline Rhinolophus blasii & $\begin{array}{c}\text { Blasius nalburunlu } \\
\text { yarasas } 1\end{array}$ & $\begin{array}{l}\text { Ormanlık, çalılık } \\
\text { fundalık }\end{array}$ & Mağaralar & $\mathrm{LC}$ \\
\hline Myotis daubentonii & $\mathrm{Su}$ yarasası & $\begin{array}{l}\text { Kirsal ve kentsel } \\
\text { alanlar }\end{array}$ & $\begin{array}{l}\text { Ağaçlar, mağaralar, } \\
\text { binalar }\end{array}$ & $\mathrm{LC}$ \\
\hline Myotis brandtii & Sakallı yarasa & $\begin{array}{l}\text { Kirsal ve kentsel } \\
\text { alanlar }\end{array}$ & $\begin{array}{l}\text { Ağaçlar, mağaralar, } \\
\text { binalar }\end{array}$ & $\mathrm{LC}$ \\
\hline Myotis capaccinii & Uzun ayaklı yarasa & $\begin{array}{l}\text { Sucul habitatlar, } \\
\text { riperian alanlar }\end{array}$ & Genelde mağaralar & VU \\
\hline Myotis mystacinus & Küçük sakallı yarasa & $\begin{array}{l}\text { Kirsal ve kentsel } \\
\quad \text { alanlar }\end{array}$ & $\begin{array}{l}\text { Ağaçlar, mağara- } \\
\text { lar, binalar, kaya } \\
\text { delikleri }\end{array}$ & $\mathrm{LC}$ \\
\hline Myotis nipalensis & Bıyıklı nepal yarasa & $\begin{array}{c}\text { Fundalık, çalılık, } \\
\text { ormanlık, çayır alan- } \\
\text { ları, çöl }\end{array}$ & $\begin{array}{c}\text { Binalar, kaya } \\
\text { yarıkları, mağaralar }\end{array}$ & $\mathrm{LC}$ \\
\hline Myotis benchsteinii & Büyük kulaklı yarasa & $\begin{array}{c}\text { Ormanlar, yapay } \\
\text { bahçeler }\end{array}$ & Ağaçlar & NT \\
\hline Nyctalus lasiopterus & Büyük akşamcı yarasa & $\begin{array}{l}\text { Ormanlar, sulak } \\
\text { alanlar }\end{array}$ & $\begin{array}{l}\text { Ağaçlar, binalar, } \\
\text { kaya yarıkları }\end{array}$ & NT \\
\hline Vespertilio murinus & Çift renkli yarasa & $\begin{array}{l}\text { Kirsal ve kentsel } \\
\quad \text { alanlar }\end{array}$ & $\begin{array}{l}\text { Ağaç, mağaralar, } \\
\text { kaya yarıkları }\end{array}$ & $\mathrm{LC}$ \\
\hline Plecotus auritus & $\begin{array}{l}\text { Kahverengi uzun kulaklı } \\
\text { yarasa }\end{array}$ & Orman & Ağaçlar & $\mathrm{LC}$ \\
\hline Barbastella barbastellus & Basık burunlu yarasa & Ormanlık & $\begin{array}{l}\text { Ağaçlar mağaralar } \\
\text { kaya aralıkları }\end{array}$ & NT \\
\hline Miniopterus schreibersii & Uzun kanatlı yarasa & Orman & Mağara & NT \\
\hline
\end{tabular}

VU: Hassas (Yaban hayatında soyu tükenme tehlikesi ile karşı karşıya olan türler)

NT: Neredeyse Tehdit Altında (Şu anda soyu tehlikede olmayan ancak yakın zamanda tehlike altına girebilecek türler)

LC: Asgari Endișede (Yaygın ve tehdit seviyesi en düşük olan türler) 
Tablo 2. Yaygın ancak koruma önceliği olan yarasa türleri

Table 2 . Widespread bat species with protection priority

\begin{tabular}{|c|c|c|c|c|}
\hline Türler & Türkçe ismi & Beslenme yerleri & Tüneme yerleri & $\begin{array}{c}\text { IUCN } \\
\text { tehlike } \\
\text { kategorisi }\end{array}$ \\
\hline Myotis emerginatus & Çentikli yarasa & Ormanda bulunabilir & Genelde mağaralar & $\mathrm{LC}$ \\
\hline Myotis capaccinii & Uzun ayaklı yarasa & $\begin{array}{c}\text { Sucul habitatlar, riperian } \\
\text { alanlar }\end{array}$ & Genelde mağaralar & VU \\
\hline Myotis nattereri & Saçaklı yarasa & Ormanlar, sulak alanlar & Ağaçlar, mağara, bina & $\mathrm{LC}$ \\
\hline Myotis schaubi & İran saçaklı yarasa & Orman, fundalık, çalılık & $\begin{array}{l}\text { Mağara, kaya } \\
\text { çatlakları, binalar }\end{array}$ & $\mathrm{LC}$ \\
\hline Myotis alcathoe & Bıyıklı yarasa & Ormanlık & Ağaçlar, mağaralar & $\mathrm{LC}$ \\
\hline Nyctalus leisleri & Ağaç yarasası & Ormanlık & $\begin{array}{l}\text { Ağaçlar, binalar, } \\
\text { mağaralar }\end{array}$ & $\mathrm{LC}$ \\
\hline Nyctalus noctula & $\begin{array}{l}\text { Bayağ1 akşamc1 } \\
\text { yarasa }\end{array}$ & $\begin{array}{l}\text { Sulak alanlar, meralar, } \\
\text { ormanlık alanlar }\end{array}$ & $\begin{array}{l}\text { Ağaçlar, kaya yarıkları, } \\
\text { binalar, mağaralar }\end{array}$ & $\mathrm{LC}$ \\
\hline Eptesicus serotinus & $\begin{array}{l}\text { Geniş kanatlı } \\
\text { yarasa }\end{array}$ & $\begin{array}{c}\text { Fundalık, çalılık, } \\
\text { ormanlık, çayır alanları, } \\
\text { açık alanlar }\end{array}$ & $\begin{array}{c}\text { Ağaçlar, binalar, kaya } \\
\text { yarıkları }\end{array}$ & $\mathrm{LC}$ \\
\hline Pipistrellus pygmaeus & $\begin{array}{l}\text { Akdeniz cüce } \\
\text { yarasas } 1\end{array}$ & Orman ve sulak alan & $\begin{array}{c}\text { Ağaçlar, kaya yarıkları, } \\
\text { binalar, }\end{array}$ & $\mathrm{LC}$ \\
\hline Pipistrellus nathusii & Pürtük derili yarasa & Ormanlar, sulak alanlar & $\begin{array}{l}\text { Ağaç, mağaralar, } \\
\text { binalar }\end{array}$ & $\mathrm{LC}$ \\
\hline Hypsugo savii & $\begin{array}{l}\text { Savinin cüce } \\
\text { yarasası }\end{array}$ & Dağlık seyrek bitki örtüsü & $\begin{array}{c}\text { Ağaç delikleri kaya } \\
\text { yarıkları }\end{array}$ & $\mathrm{LC}$ \\
\hline Otonycteris hemprichii & $\begin{array}{c}\text { Uzun kulaklı çöl } \\
\text { yarasası }\end{array}$ & Kurak yaşam & $\begin{array}{l}\text { Mağaralar kaya } \\
\text { yarıkları }\end{array}$ & $\mathrm{LC}$ \\
\hline
\end{tabular}

Yaygın, ancak korunma hassasiyeti olan türler: Türkiye'de yaygın olan, ancak uluslararası koruma statüsü (IUCN) itibariyle düşük tehdit içinde değerlendirilen türlerdir. Bu türlerin Türkiye'deki popülasyon durumu çok fazla bilinmemekle birlikte, nadiren rastlanan türler olarak değerlendirilmiştir (Yorulmaz ve ark., 2016; Yorulmaz ve Arslan 2016a, 2016b). Yaşam alanları da dikkate alınarak koruma hassasiyeti gereken türler Tablo 2'de belirtilmiştir.

En az etkilenecek türler (Düşük düzeyde korunma ihtiyacı olan türler): Bu türler hem uluslararası koruma statülerince (IUCN, 2017) hem de Türkiye'deki dağılımları, popülasyon durumlar1 (Yorulmaz ve ark., 2016; Yorulmaz ve Arslan 2016a, 2016b) ile ilgili tahminler ve yüksek habitat çeşitliliğine sahip olmaları bakımından bu kategoride yer almışlardır (Tablo 3).

Orman alanlarında uzman kişilerce yapılacak olan tür tespiti, aktivite yoğunluğu ve orman alanının yarasalar tarafından kullanım durumu gibi verilerin elde edilmesinden sonra yukarıda farklı kategorilerde önerilmiş olan türlerle ilgili olarak;

Orman alanında ve yakınlarında bulunacak mağaraların mutlak koruma altına alınması gerekmektedir. $\mathrm{Bu}$ mağaraların özellikle giriş kısımlarının ormancılık faaliyetlerinden etkilenmemesi için giriş kısımlarına $100 \mathrm{~m}$ mesafede bir alanın koruma zonu olarak belirlenmesi önerilmektedir. Ayrıca Şekil 2'te anlatıldığı gibi orman içinde tüneme özelliği taşıyan ağaçların belirlenmesi ve korunması önerilmektedir. Bununla birlikte bu türlerin tespit edildiği alanlarda orman ağaç kompozisyonu da korunmalıdır.

Yarasaların ses kayıtlarının alındığı bölgelerde yani beslenme davranışı sergiledikleri alanlarda bireysel ağaç kesiminden çok fazla etkilenmemekle birlikte 
Tablo 3. En az etkilenecek olan yarasa türleri

Table 3. Bat species to be affected least (LC)

\begin{tabular}{|c|c|c|c|c|}
\hline Türler & Türkçe ismi & Beslenme yerleri & Tüneme yerleri & $\begin{array}{c}\text { IUCN } \\
\text { tehlike } \\
\text { kategorisi }\end{array}$ \\
\hline Taphozous nudiventris & $\begin{array}{c}\text { Çıplak karınlı } \\
\text { yarasa }\end{array}$ & $\begin{array}{c}\text { Ormanlık alan düz yerler } \\
\text { nehir kenarları }\end{array}$ & $\begin{array}{c}\text { Kaya yarıkları, çat- } \\
\text { lakları mağaralar, } \\
\text { mezarlar }\end{array}$ & $\mathrm{LC}$ \\
\hline $\begin{array}{l}\text { Rhinolophus ferrumequ- } \\
\text { inum }\end{array}$ & $\begin{array}{c}\text { Büyük nalburunlu } \\
\text { yarasa }\end{array}$ & Kırsal ve kentsel alanlar & $\begin{array}{l}\text { Ormanlar, binalar, } \\
\text { mağaralar, yarıklar }\end{array}$ & $\mathrm{LC}$ \\
\hline Rhinolophus hipposideros & $\begin{array}{c}\text { Küçük nalburunlu } \\
\text { yarasa }\end{array}$ & $\begin{array}{l}\text { Yaprak döken ormanlar, } \\
\text { ormanların kenarları }\end{array}$ & $\begin{array}{c}\text { Doğal yapay mağaralar } \\
\text { bina çatıları }\end{array}$ & $\mathrm{LC}$ \\
\hline Myotis myotis & $\begin{array}{c}\text { Büyük farekulaklı } \\
\text { yarasa }\end{array}$ & $\begin{array}{l}\text { Ormanlık alan düz } \\
\text { yerler nehir kenarları }\end{array}$ & Mağaralar & $\mathrm{LC}$ \\
\hline Myotis aurascens & $\begin{array}{c}\text { Bozk1r b1y1kl1 } \\
\text { yarasası }\end{array}$ & Ormanlık ve çalılık & $\begin{array}{c}\text { Kaya yarıkları } \\
\text { çatlakları }\end{array}$ & $\mathrm{LC}$ \\
\hline Myotis blythii & $\begin{array}{c}\text { Küçük farekulaklı } \\
\text { yarasa }\end{array}$ & $\begin{array}{l}\text { Tarım arazileri, bodur } \\
\text { çayır habitatları }\end{array}$ & $\begin{array}{c}\text { Mağaralar, eski } \\
\text { binalar, madenler }\end{array}$ & $\mathrm{LC}$ \\
\hline Eptesicus bottae & $\begin{array}{l}\text { Akdeniz geniş } \\
\text { kanatlı yarasa }\end{array}$ & Tarım alanları & $\begin{array}{l}\text { Kaya yarıkları, } \\
\text { mezarlar binalar }\end{array}$ & $\mathrm{LC}$ \\
\hline Pipistrellus pipistrellus & Cüce yarasa & $\begin{array}{c}\text { Ormanlık, tarım arazileri } \\
\text { orman kenarları }\end{array}$ & $\begin{array}{l}\text { Ağaçlar, mağara, kaya } \\
\text { yarıkları, binalar }\end{array}$ & $\mathrm{LC}$ \\
\hline Pipistrellus kuhlii & Beyaz şeritli yarasa & $\begin{array}{c}\text { Tarımsal ve kentsel } \\
\text { alanlarda }\end{array}$ & $\begin{array}{l}\text { Ağaç, kaya yarıkları, } \\
\text { binalar }\end{array}$ & $\mathrm{LC}$ \\
\hline Plecotus Austriacus & $\begin{array}{c}\text { Gri uzun kulakl1 } \\
\text { yarasa }\end{array}$ & $\begin{array}{c}\text { Tarımsal araziler, ovalar } \\
\text { vadiler }\end{array}$ & $\begin{array}{l}\text { Kaya yarıkları, } \\
\text { mağaralar }\end{array}$ & $\mathrm{LC}$ \\
\hline Plecotus Kolombatovici & $\begin{array}{l}\text { Balkan uzun } \\
\text { kulaklı yarası }\end{array}$ & Tarımsal alanlar sokaklar & Mağara ve çatlaklar & $\mathrm{LC}$ \\
\hline Plecotus Macrobullaris & $\begin{array}{c}\text { Dağ uzun kulaklı } \\
\text { yarasası }\end{array}$ & Dağlık alan & Mağara ve çatılar & $\mathrm{LC}$ \\
\hline Tadarida Teniotis & Kuyruklu yarasa & Dağlık alan yarı çöl alan & $\begin{array}{l}\text { Kayalık habitatlar } \\
\text { boşluklar }\end{array}$ & $\mathrm{LC}$ \\
\hline
\end{tabular}

daha çok büyük alanları içeren tıraşlama benzeri faaliyetlerden olumsuz etkilenecektir. Bu sebeple, izleme ve etki azaltıcı tedbirlerin alınması şartıyla ses kayıtlarının veya izlerin tespit edildiği alanlarda habitat özelliğinin tamamen değişimine yol açmayacak küçük çaplı faaliyetlere izin verilmelidir.

$\mathrm{Bu}$ çalışma ile ormanlardaki yarasalar hakkında öncül bilgiler derlenmiş ve öneriler sunulmuştur. $\mathrm{Bu}$ konu ile ilgili daha detaylı çalışmalara ihtiyaç duyulmaktadır. Türkiye'nin orman ve yarasa varl1ğının yanı sıra, gelecekte insan faaliyetlerinin orman alanlarını daha fazla etkileyecek olması gerçeği de dikkate alındığında, bu konudaki araştırma ve koruma çalışmalarına ihtiyacın artacağı da göz önünde tutulmalıdır.

\section{Kaynaklar}

Albayrak, İ., Aşan, N. 1999. Distributional Status of the Bats from Turkey. Communications of the Faculty of Sciences of the University of Ankara, Series C, 17(1/2): 59-68.

Altringham, J.D. 1996. Bats: Biology and Behaviour. Oxford University Press, Oxford; New York, 262 p.

Anonim 1, 2015. www.yorkshiredales.org.uk/ /Batsin-trees-Oct-2015.pdf (Erişim tarihi: 2 Ocak 2018)

Anonim 2. OGM Orman zararlilar1 ile mücadele esaslar1. https://www.ogm.gov.tr/ekutuphane/Tebligler/Orman $\% 20$ Zararl $\%$ C4\%B1lar\%C $4 \% \mathrm{~B} 1 \% 20$ $\%$ C $4 \%$ B 01 e $\% 20$ M \% C $3 \%$ B C c a d e 1 e $\% 20$ Esaslar\%C4\%B1.pdf 
Anonim 3, 2018. http://treeheritage.co.uk/bats-birdsand-other-wildlife/ (Erişim tarihi: 2 Ocak 2018)

Anthony, E.L.P., Kunz, T.H. 1977. Feeding strategies of the little brown bat, Myotis lucifugus, in southern New Hampshire. Ecology, 58: 775-786.

Bogdanowicz, W., Rajan, K. E., Arasamuthu, A. S., Marimuthu, G., Dabrowski, M., 2014. Baby sitting and aspects of non-maternal infant support in the carnivorous bat Megaderma lyra. XIIIth European Bat Research Symposium, 1- 5 th September 2014, Siberik, Crotia.

Brigham, R.M., R.M.R. Barclay, J.M. Psyllakis, D.J.H. Sleep, and K.T. Lowrey. 2002. Guano traps as a means of assessing habitat use by foraging bats. Northwest Naturalist $85: 15-18$.

Dietz C, von Helversen O, Nill D., 2009. Greater Noctula Bat Bats of Britain, Europe \& Northwest Africa (English Edition). UK:A \& C Black Publishers Ltd., London

Eken G, Bozdogan M, İsfendiyaroglu S, Kılıç DT, Lise Y. 2006. Türkiye'nin Önemli Doğa Alanlar1. (Turkey's Key Biodiversity Areas). Doğa Derneği \& Kitap Yay1nevi, İstanbul. II Volumes - 1200 pp.

Evelyn, M. J., D. A. Stiles, and R. A. Young. 2004. Conservation of bats in suburban landscapes: roost selection by Myotis yumanensis in a residential area in California. Biological Conservation 1 15:463-473

Findley, 1972. J.S., Phenetic Relationships among Bats of the Genus Myotis. Systematic Biology. 21 (1): 31-52.

Humphrey, S.R., 1975. Nursery Roosts and Community Diversity of Nearctic Bats. Journal of Mammalogy, Volume 56, Issue 2, 30 May 1975, Pages 321-346.

Hundt L 2012. Bat Surveys: Good Practice Guidelines, 2nd edition, Bat Conservation Trust 1-99.

Hutson AM, Mickleburgh SP, Racey PA 2001 Microchiropteran bats: global status survey and conservation action plan. IUCN/SSC Chiroptera Specialist Group, $\mathrm{p}$ $36-46$

IUCN Redlist of threatened species, version 2017-3. <www. IUCNRedlist. org>. (Erişim tarihi: 2 Ocak 2018)

Jackson, 2015. The Leaflet of Bats \& Trees www.bats. org.uk/data/files/publications/Bats_Trees.pdf (Erişim tarihi: 2 Ocak 2018)

Kunz, T.H. (Ed.) 1988. Ecological and Behavioural Methods for the Study of Bats. Smithsonian Institution Press, Washington, D.C.

Kunz TH, Thomas DW, Richards GC, Tidermann CR, Pierson ED, Racey PA (1996) Observational techniques for bats. In: Wilson DE, Cole FR, Nichols JD, Rudran R, Foster MS (eds) Measuring and monitoring biological diversity, standard methods for mammals. Smithsonian Institute Press, Washington and London,pp 105-114
Kunz, T.H., 1996. Methods of marking bats. In: Wilson, D.E., Cole, F.R., Nichols, J.D., Rudran, R., Foster, M.S. (Eds.),ARTICLEINPRESSM. Muñoz-Romo et al. / Mamm. biol. 73 (2008) 214-221220Measuring and Monitoring Biological Diversity. Standard Methods for Mammals. Smithsonian Institution Press, Washington, DC, pp. 304-310.

Lacki, Michael J.; Hayes, John P.; Kurta, Allen, eds. 2007. Bats in forests: Conservation and management. Baltimore, MD: The Johns Hopkins University Press: 177-205

Lunney, D., Barker, J., Priddel, D., and O'Connell, M. 1988. Roost selection by Gould's long-eared bat, Nyctophilus gouldi Tomes (Chiroptera: Vespertilionidae), in logged forest on the south coast of New South Wales. Aust. Wildl. Res. 15: 375-384.

Merrit, J.F. 2010. The biology of small mammals. The Johns Hopkins University Press. Baltimore, 1-312, 2010.

Neuweiler, G. 1990. Auditory adaptations for prey capture in echolocating bats. Physiological Reviews, Vol. 70. No.3, July 1990. Pages 615-637. Printed in USA.

Neuweiler, G. 2000. The biology of bats. New York: Oxford University Press. $310 \mathrm{p}$.

Nowak, R.M. 1994. Walker's Bats of the World. Baltimore (MD): The Johns Hopkins University Press, 287 p.

Nowak, R.M. 1999. Walker's Mammals of the World. 6th ed. Baltimore: The Johns Hopkins University Press, $836 \mathrm{p}$.

OGM, 2015. Türkiye Orman Varlığı 2015. Orman ve Su İşleri Bakanlığı, Orman Genel Müdürlüğü, Ankara.

OGM 2016. Orman Bitkilerinde Zararlı Ve Hastalıklarla Mücadelede Kullanılan İlaçlar., CTA Reklam Hiz. Bas. Yay. Ltd. Şti. Ankara

O'Shea, T. J., Bogan, M. A., 2003. Introduction. Pp. 1-7 in O'Shea, T. J. and M. A. Bogan (eds.), Monitoring trends in bat populations of the United States and territories: problems and prospects. U.S. Geological Survey, Information and Technology Report 2003-003, 274 pp.

Perry, RW., 2011. A Review Of Fire Effects On Bats And Bat Habitat In The Eastern Oak Region, Proceedings of the 4th Fire in Eastern Oak Forests Conference, Springfield, MO, May 17-19, GTR-NRS-P-102, 170-191 pp

Racey, P.A. 1982. Ecology of bat reproduction. In: Ecology of bats, Ed. by I. Kunz, H. Thomas. New York: Plenum Publishing Corporation, pp. 57-68.

Richardson, E., P., 2011. Bats. Natural History Museum Life Sciences. London Natural History Museum, London, 1-128.

Schober, W., Grimmberger, E. 1997. The Bats of Europe and North America. T.F.H. Publications, USA., 239 p. 
Speakman, JR, Thomas, DW, 2003. Physiological ecology and energetics of bats. In: Kunz TH, Fenton MB (eds) Bat ecology. University of Chicago Press, Chicago, pp 430-492.

Taylor, DAR., 2006. Forest Manegement and Bats. Bat Conservation International, 1-14.

Tillon L., Bouget C., Paillet Y., Aulagnier S., 2016. How does deadwood structure temperate forest bat assemblages? Eur. J. For. Res., 135(3): 433-449.

Yorulmaz, T., 2013. Rüzgar Enerjisi ve Yarasalar (Tam Metin Bildir).Türkiye Yarasaları Sempozyumu I, 25-26 Ekim 2013-Balıkesir.

Yorulmaz T, Arslan N, 2016a. Türkiye Yarasalarının (Mammalia: Chiroptera) Son Durumu ve Ulusal Korunma Statüleri İçin Öneriler (Poster Sunum) 23. Ulusal Biyoloji Kongresi, 5-9 Eylül 2016, Gaziantep.

Yorulmaz T, Arslan N. 2016b. Türkiye Yarasaları ve Ekolojik Tercihleri. Uluslararası Ekoloji 2016 Adnan Aldemir Sempozyumu, 16-19 May1s 2016, Kars.

Yorulmaz T, Yetkin D, Arslan N, Erdoğan A. 2016. Türkiye Yarasalarında Aktivite Yoğunluğunun Sicaklık,
Rüzgâr Hızı, Yükseklik ve Bitki Örtüsü ile ilişkisinin Belirlenmesi 23. Ulusal Biyoloji Kongresi, 5-9 Eylül 2016, Gaziantep.

Waldien, D.L., and J.P. Hayes. 2001. Activity areas of female long-eared Myotis in coniferous forests in western Oregon. Northwest Science 75: 307-314.

Vonhof, M.J., H. Whitehead, and M.B. Fenton. 2004. Analysis of Spix's disk-winged bat association patterns and roosting home ranges reveal a novel social structure among bats. Animal Behaviour 68:507-521.

Whitaker, J.O.Jr. 1995. Food of the big brown bat, Eptesicus fuscus, from maternity colonies in Indiana and Illinois. American Midland Naturalist, 134: 346-360.

Wilkinson, G.S., South, J.M. 2002. Life history, ecology and longevity in bats. Aging Cell, 1(2): 124-131.

Wilson, D.E., Reeder, D.A.M., 2005. Mammal Species of the World: A Taxonomic and Geographic Reference, 2. Cilt., JHU Press.

Zeale MRK, Butlin RK, Barker GLA, Lees DC, Jones G. 2011. Taxon-specific PCR for DNA barcoding arthropod prey in bat faeces. Mol Ecol Res. 236-244. 